\title{
Annual Congress of the South-Eastern Union of Scientific Societies.
}

THE thirty-third congress of the South-Eastern Union of Scientific Societies took place at Rochester on June 6-9, with Sir Martin Conway, M.P., in the presidential chair. The congress was well attended, and delegates were sent from most of the seventy-four societies comprised in the Union.

Sir Martin Conway's address was on "Mountain Exploration." The Matterhorn, Sir Martin said, was once thought to be the abode of evil spirits, and even now we find little chapels at the base of mountains, the object being to dam back the evil spirits from descending into the valleys. In the Andes of Bolivia the mountains were held to be the abode of gods. Indeed, almost all over the world the mountains were held to be the abode of either devils or gods. In the Chinese mind there is a great love for the mountains, and many poems have been dedicated to them; this affection is exceptional amongst the peoples of the world.

Sir Martin said that, geologically, mountains are quite modern, some of the youngest being found in the Himalayas, and the hundreds of peaks there have not yet been worn down as in the case of other ranges, as, for example, the Scottish mountains, where denudation has gone on for a much longer period. Mountains are continually being broken down by the forces of Nature, and at periods in geological history fresh mountains have been reared up from the crust, making up for the denudation of other ranges. In Great Britain, as in other countries, it was only during the course of the last century that people began to see beauty in great heights, and poetry and art have done much since to beget a love for mountain climbing.

Respecting the breaking down of mountains, Sir Martin said he has seen as many as eighteen avalanches in one hour in the Himalavas. In the same range there are great glaciers and great precipitation of snow. The South American Andes are in the main poorly supplied with snow, and the glaciers are as a rule eaten up by evaporation before they reach a low level. On the other hand, in Spitsbergen, although the highest of the mountains is but 7000 feet high, they are the grandest of all, as they are clothed with snow to their base.

In Dr. William Martin's address to the archæologists, he emphasised the necessity of organised work on proper lines, and showed how such work can be prevented from being but desultory and unscientific. $\mathrm{He}$ showed what powers exist under the Ancient Monuments Act to prevent destruction of objects of interest, and emphasised the fact that such powers are very limited, and that but little can be done where there is a determined effort to do away with monuments that are in the way of modern so-called improvement. In speaking of the archæological remains in the Medway Valley, Mr. A. E. Hurse stated that he considers that the ancient highway, sometimes known as the Pilgrims' Way, which may have really dated from neolithic times, crossed the Medway somewhere near Snodland. Another ancient highway, sometimes called the Old Road, is remarkable as being in the line of many megalithic remains, such as the circles at Addington, its dolmens, and Kits Coty House. The fact that neither road was much utilised to serve as parish boundaries seems to show that they were to a great extent lost before Saxon and Norman times, when boundaries began to be defined.

Mr. G. E. Hutchings in his paper on the vegetation of the district showed that the area comprises wide chalk areas and salt marshes, and forms an admirable one for the study of plant ecology ; little work has yet been done in this direction. Papers of a botanical nature were read by Mr. C. E. Salmon, on fruits and seeds of allied plants, and by the Rev. L. Denton Sayers, on gall-formation in plants.

In the geological section Mr. H. B. Milner gave an illustrated paper on "Geology from the Air," and by the aid of numerous aerial photographs showed how the aeroplane can be utilised for geological study. During flights that he has made in Iraq and Palestine he has taken photographs which give an added interest to the geology of these districts. In thickly wooded country air pictures are particularly valuable, as they can form the basis of maps which can afterwards be more closely filled in by ordinary field work. 'Cutoffs' or ox-bow lakes can thus be identified which may be overlooked by ordinary means in such a country. The meanders of the Jordan were vividly portrayed in one of the pictures shown. English coast-line scenery takes on a new aspect from the air, whilst inaccessible regions in all mountainous parts of the earth can be studied in air pictures. Aerial geology is in its infancy, and much may be expected from it.

Dr. S. W. Wooldridge gave a characteristic paper on the geomorphology of the North Downs, and Mr. G. Dines a paper on the Bapchild palæolithic site. Prof. E. W. MacBride read a paper on the conditions of progressive evolution.

A public lecture was given by $\mathrm{Mr}$. Aymer Vallance on old timber houses, introducing many pictures to illustrate the evolution of the half-timbered houses from what is considered the neolithic plan of drawing branches of trees so as to form an arched roof, to the curved 'ships' timbers' which in early houses supported the roof. Then followed the upright timbers to support a second floor, and finally the curved timbers were used only for walls of that floor, seen outside such a house as part of the half-timbering. The houses at first had a long room or hall where the household met for meals, and many of these were later cut up so as to form a number of rooms, or even separate cottages. When rooms were added on the upper floor the heads of the family would retire to one of these, which came to be known as the 'solar,' a name that gave rise to some discussion. It was suggested that the name arose from the room being in a position exposed to the sun, but it may have been the room where the family could be alone or solus.

In the Regional Survey Section, Mr. C. C. Fagg gave a history of the movement, in the development of which he has for many years taken an active part.

Many excursions were made during the congress, some of a strictly scientific nature, those devoted to archæology being well attended. Not the least interesting was that to Gads Hill Place, which was thrown open by the kindness of the occupiers, who showed the visitors may items of interest to lovers of Dickens. A reception by the Mayor in the Guildhall was followed by a lecture by Dr. Mortimer Wheeler on Roman Rochester. The remains of the old Roman walls, the Cathedral and the Castle, the House for Six Poor Travellers, and other places in the town, were visited under local guides during a comprehensive perambulation. At the delegates' meeting the honorary secretary announced that the congress for 1929 would be held at Brighton, under the presidency of Sir Arthur Keith.

No. 3061, VoL. 121] 